Nigerian Journal of Physiological Sciences 24 (2): 129 - 135 @Physiological Society of Nigeria, 2009

Available online/abstracted at http://www.bioline.org.br/np; www.ajol.info/journals.njps; www.cas.org

\title{
EVALUATION OF THE EFFICACY OF SEPARATE ORAL SUPPLEMENTS COMPARED WITH THE COMBINED ORAL SUPPLEMENTS OF VITAMINS C AND E ON SPERM MOTILITY IN WISTAR RATS
}

\author{
S. A. OGLI, O. ENYIKWOLA* AND S. O. ODEH* \\ Department of Physiology, College of Health Sciences, Benue State University, Makurdi, Nigeria. *Department of \\ Human Physiology, Faculty of Medical Sciences, University of Jos, Plateau state, Nigeria. Email: \\ saogli@yahoo.com
}

\begin{abstract}
Summary: Infertility is a major reproductive and social problem with a worldwide prevalence of $10-15 \%$. While $11.8-39.0 \%$ of infertility cases are attributable to the female, $15.8-42.4 \%$ is attributed to the male and $8.0-11.1 \%$ to unknown factors. The study investigated the efficacy of the single versus combined regimes of antioxidant vitamins $\mathrm{C}$ and $\mathrm{E}$ oral supplements on sperm motility in the reproductively matured Wistar rats. Twenty (20) male Wistar rats aged 12 weeks and weighing between $182 \mathrm{~g}$ and $252 \mathrm{~g}$ were randomly grouped into 4 experimental blocks (A-D) of 5 rats each. Block A rats were served combined daily dose of $90 \mathrm{mg}$ vitamin $\mathrm{C}$ and $15 \mathrm{mg}$ vitamin E, block B rats had no treatment and served as control, block $\mathrm{C}$ rats were served daily dose of $15 \mathrm{mg}$ vitamin $\mathrm{E}$ only while block D rats were served daily dose of $90 \mathrm{mg}$ vitamin C only; all treatments were administered for 28 days. On the $29^{\text {th }}$ day, the rats were humanely sacrificed and semen analyzed for sperm motility. The study showed that treatment with vitamins $\mathrm{C}$ and $\mathrm{E}$ as single regime significantly improved $(p<0.01)$ the forward, progressive (category ' $\mathrm{a}$ ') mean percentage sperm motility by 70 and 75 folds respectively while significantly decreasing $(p<0.01)$ the nonprogressive (category ' $c$ ') mean percent sperm motility by 8 and 5 folds respectively compared to the control mean percent sperm motility. We therefore conclude that sperm motility in the Wistar rats is significantly improved with the separate oral supplements of vitamins $\mathrm{C}$ and $\mathrm{E}$ as compared with the combined supplements.
\end{abstract}

Key words: Infertility, antioxidant vitamins, semen, sperm motility

\section{Introduction}

One of the main reasons of mating between the male and female gender is to reproduce and produce like species. Reproduction in animals, including man, involves a chain of events with the resultant production of spermatozoa in the male and ova in the female from primordial germ cells (spermatogenesis and oogenesis respectively) (Stuart and Christoph, 2001). Diminished or absent capacity of a couple to reproduce is regarded as infertility, a term which does not connote sterility, which is the complete inability to produce offspring (Block et al, 2007).

Clinically, primary infertility is defined as the inability to achieve a recognizable pregnancy after 12 months of consistent, unprotected coitus; Secondary infertility is where a clinical pregnancy had occurred previously, but not in the last 12 months, while Voluntary infertility is where a couple or a party in the couple voluntarily interrupts the process of conception, despite regular, uninterrupted coitus (Guyton and Hall, 2003; Ericksen and Brunette, 2003). The World Health Organization (WHO), on the other hand, defines infertility as the inability of a sexually active, non-contracepting couple to achieve pregnancy in one year (WHO, 2000). Using a two year reference period, it defines primary infertility as the lack of conception despite cohabitation and exposure to pregnancy, while secondary infertility as the failure of conception following a previous pregnancy despite cohabitation and exposure to pregnancy in the absence of contraception, breast feeding or postpartum amenorrhea (WHO, 1991). Etiologically, studies have shown that the contribution to infertility by female, male and unknown factors vary from country to country. Whereas in France, the figure stands at $39 \%$ for both sexes and $8 \%$ for unknown factor (Thonnaen et al, 1991), in Ghana, $11.8 \%$ of infertility cases are due to female factor and $15.8 \%$ to male factor [Geelhoed $e t$ $a l, 2002]$. In Nigeria however, female factor, male factor and unknown factor contribute $25.8 \%, 42.4 \%$ and $11.1 \%$ to infertility cases respectively (Ikechebelu et al, 2003).

Infertility has African and worldwide prevalence of $10-20 \%$ and $10-15 \%$ respectively (Erickson and Brunette, 1996). It is associated with social embarrassment and disappointment (especially among African men), emotional consequences (Mening, 1980), family breakdown and violence against women (Ali and Bustamante-Gavino, 2007). For a couple to be adjudged fertile, apart from the female, the male needs to produce healthy semen. WHO (1992) prescribed basic and minimum semen parameters for a fertile man to include: a semen volume of at least $2 \mathrm{ml}, \mathrm{pH}$ of 7.2 to 8.0 , sperm concentration of $20 \times 10^{6}$ sperm cells $/ \mathrm{ml}$ of semen, sperm count of $40 \times 10^{6}$ spermatozoa per ejaculate, a minimum sperm motility of 50\% with forward progression (categories a and b) or $25 \%$ with rapid 
progression (category a ) within 60 minutes of ejaculation, and White blood cell (WBC) content of no more than $1 \times 10^{6} / \mathrm{ml}$.

Sexually transmissible infections (STIs) are said to be responsible for most cases of infertility in both sexes (Mayo clinic, 2006, Tukur et al, 2006), but specifically regarding infertility in the male, Okon et $a l$, (2005) observed a high incidence of asymptomatic bacteriospermia among the male partners in northern Nigeria which they attributed to be a major factor in male infertility. Equally important is the observation by Aitken, (2006) that impaired spermatogenesis and spermatozoa deoxyribonucleic acid (DNA) defect arising from oxidative stress is mainly responsible for male infertility.

Perhaps, the most disturbing of these causal factors of male infertility is low quality of spermatozoa that lack efficient motility. Studies have shown that the oxidation of unsaturated fatty acids of sperm (spermatozoa are known to have high content of polyunsaturated fatty acids) by free radicals generated from oxidants (also known as toxicants) is the major cause of unhealthy sperm (Sheena, 2007). Various chemicals implicated as reproductive toxicants, categorized as air pollutants are present in the blood, urine and semen of exposed men; these are known to affect sperm quality (Center for Disease Control and Prevention (CDC), 2001; Telisman et al, 2001). Infertile men have been known to have higher levels of reactive oxygen species (ROS), one of the free radical groups which damages sperm [Mayo clinic, 2006]. Similarly, Sokol et al, (2006) equally observed that idiopathic male infertility may be due to exposure to environmental toxicants that alter spermatogenesis or sperm function and that exposure to ambient ozone levels adversely affect semen quality with an inverse relation between ozone levels and sperm concentration.

The process of spermatogenesis can be disturbed by several factors ranging from genetic, environmental and nutritive factors to diseases that directly or indirectly affect it (Holstien et al, 1994; Nieschlag and Behre, 2001). The lack of F-actin has been reported as a factor in the production of poor quality spermatozoa (Xiang and Wan, 2007). F-actin is an essential factor in spermatid nuclear shaping. Worthy of note is the observation that a previously uncharacterized gene called spem-1 (spermatid maturation 1) is responsible for removal of residual bodies in the mouse testis. Lack of this gene is been noted to result in spermatozoa with bulky cytoplasm in the head and a kinked neck, usually with the tail piece wrapped around the neck [Huili et al, 2007]. Maintenance of this spermatogenetic process in mammals is dependent on specialized networks of gene expression programs in the testis called gonadspecific tumor activating factor $4 \mathrm{~b}$ (TAF4b), a component of TFIID (formerly $\mathrm{TAF}_{\mathrm{II}} 105$ ) which is a transcriptional regulator abundant in the mouse testis (Allison et al, 2005). It was observed that young male mice that lacked $T a f 4 b$ were initially fertile, but became infertile by 3 months of age and eventually exhibit seminiferous tubules devoid of germ cells.

Temperature is one of the environmental factors that affect spermatogenesis strongly (Sadler, 2004). Normal spermatogenesis is impaired if the testis is maintained at the normal body 'core' temperature (as occurs in cryptorchidism or by the wearing of tight under wears (Lyndon and Bunge, 1994). This is because the seminiferous tubule epithelium is sensitive to temperature variations. Thus, the testicular temperature is normally maintained at about $2^{\circ} \mathrm{C}$ and $8^{\circ} \mathrm{C}$ lower than the body temperature in man and rats respectively.

The presence or absence of some dietary substances, therapeutics, drugs, hormones and their metabolites, toxic substances or $\mathrm{x}$-ray radiation may slow the spermatogenic process or even destroy sperm cells. Thus, vitamin/nutrient deficiencies (vitamins $\mathrm{A}, \mathrm{B}$, and $\mathrm{E}$, Zinc), excess exposure to anabolic steroids, heavy metals (like cadmium and lead), radiation, dioxin, alcohol and infectious disease will adversely affect the rate of spermatogenesis. The consequence of such spermatogenic interference may be expressed in missing spermiation, reduced and/or malformed spermatid population, disturbance of meiosis and arrest of spermatogenesis at different stages (Adolf-Fredrich, Wolfang and Michail, 2003).

The deleterious effects of environmental radicals are ameliorated by the use of antioxidants. Antioxidants are substances that prevent or reduce oxidation of compounds. Virtually all the toxicants that are known to cause diseases in the body act as oxidants, generating toxic radicals in the body. Enzymatic antioxidants, however, are said to confer protection from such damages [Mayo clinic, 2006]. Several nutrients that function as antioxidants act by preventing or reducing the generation of these radicals in the body. Vitamins $\mathrm{C}$ and $\mathrm{E}$ are two examples of such antioxidants.

Vitamin C (known also as ascorbic acid) has been shown to be effective in treating sperm agglutination (Dawson, Harris and McGavity, 1983). $1 \mathrm{~g}$ of daily oral vitamin $\mathrm{C}$ is said to help increase fertility in men who have problems with sperm agglutination, while among smokers, there was an improvement in sperm quality with vitamin C administration [Dawson, Harris and Powell, 1990]. In another report, vitamin $\mathrm{C}$ is said to protect sperm from oxidative damage(s) (Fraga et al, 1991). A clinical trial has suggested that vitamin $\mathrm{C}$ might improve the sperm count, motility and even morphology in infertile men (Akmal et al, 2006).

Vitamin E, also known as $\alpha$-tocopherol ( $\alpha$ TCP), on the other hand, is uniquely suited to intercept free radicals and prevent the chain reactions 
Vitamin $\mathrm{C}$ and $\mathrm{E}$ supplementation on sperm motility

of lipid destruction. It plays a key role in protecting sperm by preventing oxidation of sperm's unsaturated fatty acids and thereby stabilizing their membrane. The study investigated the effect of and the efficacy of vitamins $\mathrm{C}$ and $\mathrm{E}$ oral supplements in the combined and single regimes on sperm motility.

\section{Materials and methods}

Acquisition and acclimatization of the rats

The research was carried out in the height of the dry season between the months of December 2007 and January 2008. Twenty (20) 7 weeks old virgin male Wistar rats were procured from the Animal house of the Pharmacology Department, University of Jos. They were housed in the Animal house of the College of Health Sciences, Benue state University, Makurdi (the research area) and reared for 5 weeks (for acclimatization and attainment of reproductive maturity) before the commencement of drug administration. During this period of acclimatization and subsequently, during the experimentation, the rats were exposed to ambient room temperature, 12hour dark/light cycle, and liberal diet of growers mash and water ad libitium. Animal care and treatment were in conformity with international standards [National academy of sciences, 1996].

\section{Experimental Design}

Weighing between 182 and $252 \mathrm{~g}$, the rats were randomized through balloting, into four experimental blocks of A, B, C and D (using the completely randomized design), with each block housing 5 rats each. Similarly, treatments were randomly assigned to blocks as follows:

Block D---vitamin C administered at a dose of 90mg/day [Mark et al, 2001]; Block B---no treatment and thus, served as Control; Block C---vitamin E administered at a dose of $15 \mathrm{mg} /$ day [Food and Nutrition Board, 2000]; Block A---combined vitamin $\mathrm{C}$ and $\mathrm{E}$ administered as per doses indicated for blocks D and C respectively. Treatments were administered orally for 28 days (4 weeks).

\section{Drug Preparation and Administration on Rats}

The drugs used in the research work as treatments were:

Commercial vitamin $\mathrm{C}$ procured in the form of Citramin ${ }^{\circledR}$ drops and Juhel ${ }^{\circledR}$ tablets respectively. The Citramin ${ }^{\circledR}$ vitamin $\mathrm{C}$ was procured as a drop of $15 \mathrm{ml}$ with a concentration of $100 \mathrm{mg} / \mathrm{ml}$, while the Juhel ${ }^{\circledR}$ vitamin $\mathrm{C}$ tablets was procured at a concentration of $100 \mathrm{mg} /$ tablet. To orally administer $90 \mathrm{mg}$ vitamin C/day [Mark et al, 2001] on the rats, a suspension of $4,500 \mathrm{mg} / 15 \mathrm{ml}$ vitamin $\mathrm{C}$ suspension was prepared by crushing 30 tablets $(3000 \mathrm{mg})$ of Juhel ${ }^{\circledR}$ vitamin C into powder and mixing same with the $15 \mathrm{ml}$ of the Citramin ${ }^{\circledR}$ suspension. The new suspension has a concentration of $90 \mathrm{mg} / 0.3 \mathrm{ml}$. Each of the rats in blocks A and D was administered $0.3 \mathrm{ml}$ of the prepared suspension.

Good $N$ natural ${ }^{\circledR}$ vitamin $E$, the commercial form of $\alpha$-Tocopherol, was procured as a gelatinous capsule with a gel volume of $1 \mathrm{ml}$, with a concentration of $666.7 \mathrm{mg} / \mathrm{ml}$. Therefore, $0.03 \mathrm{ml}$ of the Good N Natural ${ }^{\circledR}$ vitamin E gel contains $15 \mathrm{mg}$ of $\alpha$-TCP. Each rat in blocks A and C was orally administered $0.03 \mathrm{ml}$ of Good $\mathrm{N}$ natural ${ }^{\circledR}$ vitamin $\mathrm{E}$ [RDA, 2000].

\section{Dissection of Rats:}

Rat dissection was conducted in the Multipurpose Physiology Laboratory of the College of Health Sciences, Benue State University, Makurdi. On the $29^{\text {th }}$ day of the experiment $\left(1^{\text {st }}\right.$ day post drug administration), each rat was sacrificed humanely by the stunning method following which the rat was subsequently strapped astride on its back on a dissecting board. A clean incision was made on the right scrotum with a clean blade. With moderate dissection, the right testis was mobilized, exposed and removed with its ipsilateral epididymis into a beaker. The semen was milked out of the epididymis into the beaker placed in the water bath at $36^{\circ} \mathrm{C}$.

\section{Semen Analysis:}

Manual seminal analysis [Cheesbrough, 2000] was used to analyze the semen for motility. A drop of semen (about 10-15 $\mathrm{l}$ ) was collected using a dropper and applied on a clean slide. The slide was covered with a cover slip and then examined for motility under $x 40$ objective lens. Note is made of the number of spermatozoa that are motile and the nature of such motility out of a population of 20 spermatozoa (motility type is categorized into ' $a$ '- rapid, progressive motility, 'b'- slow or sluggish, progressive motility, and 'c'- non-progressive motility/immotile [WHO, 1999; Nwafia et al, 2005]). Counts obtained of the motile spermatozoa are multiplied by 5 to obtain the percentage motility in each category. Thereafter, the rats' remains were disposed by burial to prevent any hazard to health.

\section{Results}

All the mean values obtained were presented as mean \pm standard error of mean (SEM) with accepted significance level at $95 \%$ probability $(p=0.05)$. Analysis of variance (ANOVA) was used to test for significance of means while the least significance difference (LSD) was used to compare difference between significant means.

The results of semen analyses for motility are as shown in figure 1 and tables 1, 2, 3 and 4 respectively. The mean percentage sperm motility category ' $a$ ' for rats in experimental blocks A, B, C and $\mathrm{D}$ respectively were $4 \pm 5.2 \%, 1 \pm 2.85,75 \pm$ $6.2 \% * *$ and $70 \pm 15.2 \% * *$; the mean percentage 
S. A. OGLI et al

sperm motility category ' $b$ ' for blocks A-D rats were $20 \pm 23.2 \%, 14 \pm 6.8 \%, 14 \pm 5.2 \%$ and $12 \pm 3.4 \%$ respectively. For category 'c' sperm motility, the mean percentage sperm motility were $78 \pm 22.6 \%$ for block A rats, $85 \pm 8.8 \%$ for block $\mathrm{B}$ rats, $11 \pm$ $10.2 \% * *$ for block $\mathrm{C}$ rats and $18 \pm 17.9 \% * *$ for block D rats.

Table 1: \% sperm motility of rats treated with combined vitamin $C \& E($ Block $A)$

\begin{tabular}{lllll}
\hline Rats & $\begin{array}{l}\text { Weight } \\
(\mathrm{g})\end{array}$ & \multicolumn{3}{l}{ Percentage motility/categories } \\
\hline & & 'a' & 'b' & 'c' \\
1 & 239 & 10 & 20 & 75 \\
2 & 247 & 5 & 50 & 50 \\
3 & 208 & 5 & 10 & 85 \\
4 & 198 & 0 & 0 & 100 \\
5 & 191 & 0 & 20 & 80 \\
mean & $217 \pm 31$ & $4 \pm 5$. & $20 \pm 23.2$ & $78 \pm 22.6$ \\
& & 2 & & \\
\hline
\end{tabular}

Table 2: \% sperm motility of rats with no treatment (Block B)

\begin{tabular}{ccccc}
\hline Rats & Weight $(\mathrm{g})$ & \multicolumn{3}{c}{ Percentage motility / categories } \\
\hline & & 'a' & 'b' & 'c' \\
1 & 248 & 0 & 10 & 90 \\
2 & 216 & 0 & 10 & 90 \\
3 & 209 & 5 & 20 & 75 \\
4 & 182 & 0 & 10 & 90 \\
5 & 211 & 0 & 20 & 80 \\
mean & $212 \pm 26.5$ & $1 \pm 2.3$ & $14 \pm 6.8$ & $78 \pm 8.8$ \\
\hline
\end{tabular}

Table 3: \% sperm motility of rats treated with vitamin $E$ only (Block C)

\begin{tabular}{ccccc}
\hline Rats & $\begin{array}{c}\text { Weight } \\
(\mathrm{g})\end{array}$ & \multicolumn{3}{c}{$\begin{array}{c}\text { Percentage motility / } \\
\text { categories }\end{array}$} \\
\hline & & 'a' & 'b' & 'c' \\
1 & 233 & 80 & 15 & 5 \\
2 & 183 & 75 & 20 & 5 \\
3 & 231 & 65 & 15 & 20 \\
4 & 209 & 85 & 10 & 5 \\
5 & 202 & 70 & 10 & 20 \\
mean & $212 \pm 26$ & $4 \pm 5.2$ & $14 \pm 5.2$ & $11 \pm 10.2$ \\
\hline
\end{tabular}

Table 4: \% sperm motility of rats treated with vitamin $C$ only (Block D)

\begin{tabular}{ccccc}
\hline Rats & $\begin{array}{c}\text { Weight } \\
(\mathrm{g})\end{array}$ & \multicolumn{3}{c}{ Percentage motility / categories } \\
\hline & & 'a' & 'b' & 'c' \\
1 & 200 & 70 & 20 & 10 \\
2 & 228 & 80 & 15 & 5 \\
3 & 208 & 50 & 10 & 40 \\
4 & 252 & 70 & 10 & 20 \\
5 & 195 & 80 & 15 & 5 \\
mean & $217 \pm 31$ & $70 \pm 15.2$ & $12 \pm 3.4$ & $18 \pm 17.9$ \\
\hline
\end{tabular}

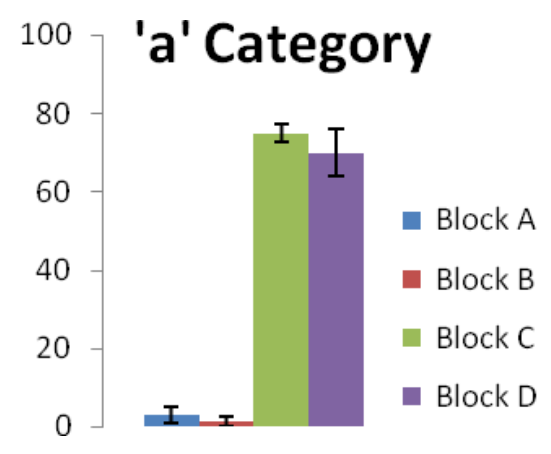

\section{'b' category}
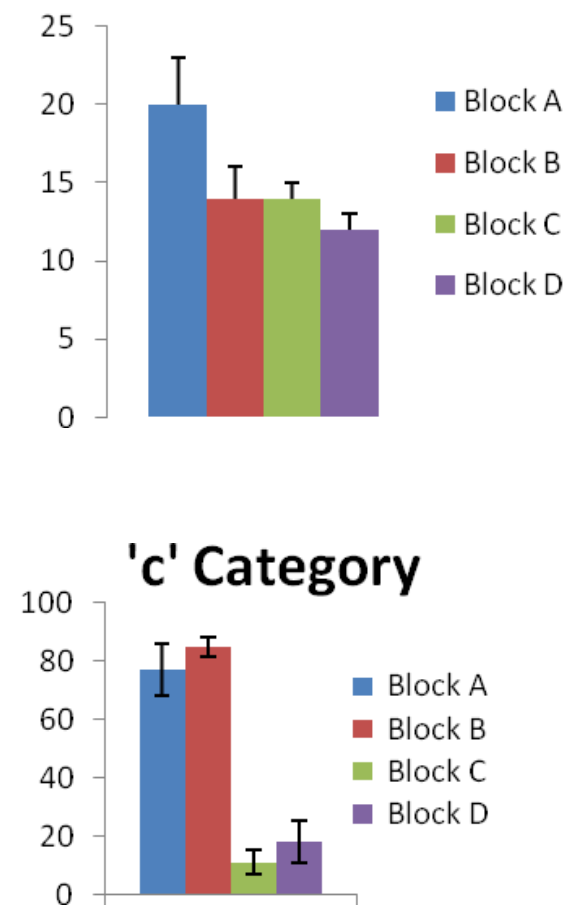

Fig. 1: Sperm motility in rats treated with vitamins $C$ and $E$ 
Vitamin $\mathrm{C}$ and $\mathrm{E}$ supplementation on sperm motility

\section{Discussion}

Infertility is a significant social and marital problem with a rising trend worldwide (Tina et al, 2000; Nwafia et al, 2006) which has always attracted the attention of clinicians and researchers alike, possibly because it touches on one of the fundamentals of human existence. There have been several attempts at ameliorating the impact of infertility through the use of food/herb, chemical/drugs and even spiritual means to improve the reproductive capacity of couples. Recently, procedure like invitro fertilization is been embarked upon for the same purpose of improving fertility among couples. For the many in the society, such procedure may be unaffordable. Thus, the search for cheaper means of managing infertility has become very imperative. This accounted for the use of vitamins $\mathrm{C}$ and $\mathrm{E}$, which otherwise, could be termed as food supplements.

Infertility intervention can only be effective in the presence of the right reproductive/physiological age and body weight (it has been shown that overweight with its attendant hypercholesterolaemia is known to cause testicular atresia in rats (Shalaby et $a l, 2004)$, maturation of the accessory reproductive glands (like the pancreas, thyroid, the adrenals) and the availability of essential macro- and micronutrients. The rats used in this study were 12 weeks of age and had a mean weight of $214 \pm 9.8 \mathrm{~g}$. Studies done elsewhere used rats with similar weights (Andrew and Josiah, 2008).

The male factor contribution to the incidence of infertility is significant at $15.8-42.4 \%$ (Ikchebelu, 2003). The causes of male infertility could be infective and/or non-infective. These non-infective agents (like testicular torsion, varicocele, chronic malnutrition of macro/ micronutrient types and exposure to toxins of both chemical and radioactive type among others) are particularly noted to affect spermatogenesis. Chemical toxins known to be present in the environment in the form of oxidants have been known to harm cells with high mitotic index like the sperm cells (Sram et al, 1996). In the early and immature sperm cells, these radicals have the ability to interrupt the methylation of DNA (Aitken, 2006) while at same time, causing structural damage to such cells through the oxidation of their fragile polyunsaturated fatty acids. These result in the production of unhealthy sperm cells.

The study focused on the efficacy of the combined oral vitamin $\mathrm{C}$ and $\mathrm{E}$ supplements compared with the single supplement on the sperm motility of the Wistar rats. The findings of this study showed that there was a 70 and 75 fold increase in the rapid and progressive (category 'a') sperm motility due to treatment with separate oral supplements of vitamin $\mathrm{C}$ and $\mathrm{E}$ respectively above that of the control (tables 3 and 4, fig 1'a' category).
The separate vitamin treatment also significantly reduced the non-progressive/immobile (category ' $c$ ') sperm motility by 8 and 5 fold respectively when compared to that of the control block. The combined vitamin supplements however, showed no significant effect on sperm motility in any of the motility categories.

These findings are supported by those of Shalaby et al (2004) where they showed that the administration of $\alpha$-TCP or Simvastastin (an antihyperlipidaemic and antioxidant agent) as sole supplement caused an improvement in seminal fluid indices like motility, but they observed a remarkable improvement of these indices when $\alpha$-TCP and Simvastastin are co-administered together. Other studies done with vitamin $\mathrm{C}$ only supplement that lends credence to the findings of this study are those of Dawson et al $(1983,1990)$ and Akmal et al, (2006) which showed that vitamin C administration improve sperm motility, count and morphology. Similarly, Yarube et al, (2008) and Afolabi et al, (2008) in their separate studies with vitamins C and E showed that the antioxidant effects of these vitamins were more remarkable when used as separate supplements, with improvements in sperm counts and related indices. The later author particularly noted that co-administering these vitamin supplements showed no significant effect on any of the sperm indices; a finding similar to that of this study evidenced by the low mean $\%$ active sperm motility as seen in table 1 .

The observed effects of vitamin $\mathrm{C}$ on sperm motility appear to be related to cellular enzymatic activities of the vitamin, which are both antioxidant and non-antioxidant. Vitamin $\mathrm{C}$ is crucial to the formation of quality sperm DNA by acting as a coenzyme in the methylation of DNA. A healthy spermatozoon is a function of healthy DNA. Acting as antioxidant, vitamin $\mathrm{C}$ prevents mitochondrial respiration defects arising from oxidative stress (Kazuto et al, 2006). It is worthy of note that the sperm motility is highly dependent on the quantity and quality of mitochondria in the tail segment. Its been observed that vitamin $\mathrm{C}$ specifically acts as coenzyme mediating the reduction of oxidized components of the $\mathrm{Cu}^{2+}$ and $\alpha$-keoglutarate-linked $\mathrm{Fe}^{2+}$ containing hydrolases in the body (Robert, Darl and Victor, 2006) as well as acting as a kinase inhibitor (Juan et al, 2004). These actions of vitamin $\mathrm{C}$ could have contributed in one way or the other to the observed outcome on sperm motility.

Vitamin K, on the other hand, acts solely as antioxidant by trapping free radicals in the body and in turn, forming tocopheroxy radical. This action is greatly enhanced by vitamin $\mathrm{C}$ as it reduces the tocopheroxyl radical, thereby regenerating vitamin $\mathrm{E}$. Inferentially, the effect of the combined supplements of vitamins $\mathrm{C}$ and $\mathrm{E}$ on sperm motility should be 
significantly better than that of any of the single supplements. However, the findings of this study suggest the contrary. No possible explanation can be giving for this yet. This calls for more studies on the subject matter, especially in higher animals.

In conclusion, the study showed that the separate oral supplements of the antioxidant vitamins $\mathrm{C}$ and $\mathrm{E}$ are significantly improved sperm motility as an index of sperm quality in the Wistar rats better than the combined supplements.

\section{References}

Adolf-Friedrich H, Wolfgang, and Michail (2003): Understanding spermatogenesis is a prerequisite for treatment; Reprod Biol Endocrinol. 1: 107

Afolabi A O, Olotu O, Togun V A, Olabiri B M and Raji Y D (2008). Vitamins C and E alleviate the oxidative stress of cryptorchidism in the rat separately, but not when combined; Abstract presented at the XXVIII ${ }^{\mathrm{TH}}$ Annual scientific conference of the Physiological Society of Nigeria, Ilorin 2008.

Aitken R. J (2006): Sperm function tests and fertility, sperm survival and fertility. Mol. Cellular Endocrinol. 250, 66-69.

Akmal M, Qadri J, Al-Wali N, Thangal S, Hag A, Saloom K (2006); Improvement of human semen quality after oral supplementation of vitamin C. $J$ Med Food; 9 3: 440-2.

Ali, T. S and Bustamante-Gavino, I (2007). Prevalence of and reasons for domestic violence among women from low socioeconomic communities of Karachi. Mediterranean Health J. 13, 6: 1417-1426.

Allison E. Falender, Richard N. Freiman, Kenneth G. Geles, Kirk C. Lo, KeumSil H, Dolores J. L, Patricia L. M, Robert T, and Joanne S. R (2005). Maintenance of spermatogenesis requires TAF $4 \mathrm{~b}$, a gonad-specific subunit of TFIID. Genes Dev; 19, 7: 794-803.

Andrew O. E and Josiah O. A (2008): Histological studies of the effects of Oral administration of Artesunate on the stomach of adult Wistar rats: The Internet J. Health. 7, 1.Abst.

Block A. W., Borer W. Z., Bruce B. B., Drake R. L., Jangid A. K., John D. T., Pucci C. L., Silver J. K., Vogl W. and Whitman W. B. (2007): Dorland's illustrated Medical dictionary, International ( $\left.31^{\text {st }}\right)$ ed. pp 950; Saunders Elsevier.

Center for Disease Control ([CDC] 2001). National Report on Human Exposure to Environmental Chemicals. Atlanta, GA.

Cheesbrough Monica (2000): Examination of Semen. District Laboratory practice in Tropical Countries, part II: Low price ed. pp 130-132; Cambridge University press.
Chukwudebelu, W. O (1978): The male factor in infertility, the Nigerian experience. Int. J. Fert. 23: 238-240.

Dawson, E. B, Harris W. A, McGavity W. J (1983): Effects of Ascorbic acid on sperm fertility. Fed Proct; 42: 531 Abst 31403.

Dawson, E. B, Harris W. A, Powell L. C (1990): "Relationship between Ascorbic acid and male infertility" in aspects of some vitamins, minerals and enzymes in health and disease. (Editor G. H. Bourne). World Rev Nutr Diet; 62: 1-2 (Review).

Derek, L. J (1986): Childlessness or infertility; fundamentals of Obstetrics and Gynecology, 2; $4^{\text {th }}$ ed. Pp 180.

Ericksen K and Brunette T (1996): Patterns and predictors of infertility among Africans women; cross sectional survey of 27 nations. Social Sc \& Medicine; 42, 2: 209-220.

Fisch H and Goluboff E. T (1996): Geographic variations in sperm count; a potential cause of bias in studies of semen quality. Fertil Steril; 65: 1044-1046.

Geelhoed DW, Nayembil D, Asare K, Schagen van Leeuwen JH, van Roosmalen J (2002): Infertility in rural Ghana. Int J. Gyn Obstet. 79 (2): 137-42.

Guyton, A. C and Hall J. E (2003): Vitamins, spermatogenesis, pregnancy and lactation. Textbook of medical physiology, $10^{\text {th }}$ ed (Indian); Elsevier. Pp 812, 916-919, 944-945.

Ho Lee (1996): The protective roles of vitamins E and $\mathrm{C}$ as antioxidants in semen. Nutrition Bytes; 2 (1): Article 4. Abst

Huili Z, Clifford J. S, Kazuto M, Jingling J, Ryuzo Y, and Wei Y (2007). Lack of Speml causes aberrant cytoplasm removal, sperm deformation, and male infertility; Proc Natl Acad Sci, USA; 104 (16): Abst.

Ikechebelu J.I, Adinma J. I.B, Orie E.F, Ikegwuonu S.O. (2003). High prevalence of male infertility; Journal of Obs and Gyn, 23: 657-59.

Jaquier A. N. (2005): Is quality assurance in semen analysis still really necessary; a clinician viewpoint. Human Rep; 20: 2039-2042.

Juan M C, Alicia P, Oriana B, Bing Z, Roberto S and David W G (2004); Vitamin C is a kinase inhibitor. Mol Cell Biol; 24 (15): 6645-6652.

Kazuto Nakada, Akitsugu Sato, Kayo Yoshida, Takashi Morita, Hiromitsu Tanaka, Shin-Ichi Inoue, Hiromichi Yonekawa, and Jun-Ichi Hayashi (2006). Mitochondria-related male infertility; Proc Natl Acad Sci U S A; 103 (41): 15148-15153.

Lyndon, O and Bunge, R. G. (1994): Semen analysis, evidence for changing parameters of fertility potential. Fert Steril; 25: 503-505.

Mark L, Yaohui W, Sebastian J. P, and Jason M. (2001): A new recommended dietary allowance of 
Vitamin $\mathrm{C}$ and $\mathrm{E}$ supplementation on sperm motility

vitamin $\mathrm{C}$ for healthy young women. Proc Natl Acad Sci U S A; 98 (17): 9842-9846.

Mayo clinic publ (Dec 2006): Healthy sperm; optimizing your fertility. Embody health, reliable tools for healthier lives.

Mening, E. C. K. (1980). Emotional needs of the infertile couple. Fert. Steril 34:313.

National academy of sciences (1996): Guide for the care and use of Laboratory Animals, National Academy press, Wahington DC.

Nieschlag, E, Behre, H. M (2001). Andrology. Male reproductive health and dysfunction. Berlin, Heidelberg, New York: Springer.

Nwafia, W. C, Igweh, J. C, Udebuani, I. N (2006): Semen analysis of infertile Igbo males in Enugu, Eastern Nigeria. Niger. J. Physiol. Sci. 21(1-2): 67-70.

Okon K. O, Nwaogwu M, Zailani S. O and chama C (2005): Pattern of seminal fluid indices among infertile male partners attending the Infertility Clinic of University of Maiduguri Teaching Hospital. Highland Med J. 3 (1). [Abst]

Pacey A. A. (2006): Is quality assurance in semen analysis still really necessary? A view from the andrology laboratory. Human Rep. 21: 11051109.

Robert K. M., Darl K G and Victor W. R, (2006): Vitamins. Harper's illustrated Biochemistry, $27^{\text {th }}$ ed. pp 494-504. McGraw Hill Lange.

Sadler, T. W. (2004): 'Spermatogenesis and Oogenesis' and 'molecular regulation of genital duct' Langman's Medical Embryology, $9^{\text {th }}$ ed. pp 18-27, 343-344; Lippincott Williams \& Wilkins. Philadelphia.

Shalaby, M. A., El-Zorba, H. Y., Kamel, G. M (2004). Effect of $\alpha$-tocopherol and simvastatin on male fertility in hypercholesterolemic rats. Pharmacological Research; 50 (2): 137-142.

Sokol Z. Rebecca, Peter Kraft, Ian M. Fowler, Rizvan Mamet, Elizabeth Kim, and Kiros T. Berhane (2006): Exposure to environmental ozone alters semen quality. Environ Health Perspect; 114 (3): 360-365.

Stuart C, Christoph L (editors; 2001); The sperm; Obstetrics by Ten Teachers, $17^{\text {th }}$ ed. ELST/AstraZeneca. Pp 37-40.

Telisman S, Cvitkovic P, Jurasovic J, Pizent A, Gavella M, Rocic B (2001): Semen quality and reproductive endocrine function in relation to biomarkers of lead, cadmium, zinc, and copper in men. Environ Health Perspect; 108:45-53.

Thomaen P, Sophie M, Annie T et al (1991): Incidence of main causes of infertility in resident population of 3 French region 1988-1989. Human Rep. 6 (6); 811-816.

Tina K, Elizabeth C, Neils J et al (Jun 2002): Poor semen quality may contribute to recent decline in fertility rates. Human Rep; 17 (6); 1437-1440.

Traber, M. G (1999); Utilization of vitamin E. Biofactors; 10 (2-3):115-120.

Tukur J, Shittu S. O, Abdul A. M (Jan 2006): A case control study of active genital Chlamydia trchomatis infection among patients with tubal infertility in Northern Nigeria; Trop. Doctor; 26 (1): 14.

World Health Organization (1987). WHO Laboratory manual for the examination of Human semen and semen-cervical mucus interaction, $2^{\text {nd }}$ ed. Cambridge University Press, Cambridge

World health organization (1992). Laboratory manual for the examination of human semen and spermcervical mucus interaction, $3^{\text {rd }}$ ed, NY; Cambridge university press.

World health organization (1999). Laboratory manual for the examination of human semen and spermcervical mucus interaction, $4^{\text {th }}$ ed, NY; Cambridge university press.

World Health Organization (2000). WHO Manual for the Standardised Investigation, Diagnosis andManagement of the Infertile Male. Cambridge: Cambridge University Press.

Xiang Xiao and Wan-xi Yang (2007). Actin-based dynamics during spermatogenesis and its significance; J Zhejiang Univ Sci B; 8 (7); 498506.

Yarube I. U, Okasha M, Ayo J. O and Olorunshola K. V (2008). Antioxidant vitamins C and E alleviate the toxicity induced by chronic NaNO3 administration on sperm count and serum testosterone level in Wistar rats; Abst presented at the XXVIII ${ }^{\mathrm{TH}}$ Annual Scientific Conference of the Physiological Society of Nigeria, Ilorin 2008.

Received: June 26, 2009

Accepted: October 31, 2009 